\title{
Persepsi Khalayak pada Tayangan Konten Gaya Hidup Sehat oleh Influencer
}

\author{
Sekar Mayang Setyo Riani, Septia Winduwati \\ sekar.915160136@stu.untar.ac.id,septiaw@fikom.untar.ac.id
}

Fakultas Ilmu Komunikasi Universitas Tarumanagara

\begin{abstract}
Communication is a way of conveying a message or information so that it can change or create perception. Nowadays the internet has grown so rapidly that Youtube has become one of the new media which is a channel to change and create perception. One perception that can be created through Youtube is about healthy lifestyles. The purpose of this study was to determine the perceptions that arose after watching Yulia Baltschun's healthy lifestyle content based on the psychology of communication theory about the process of perception formation. The author conducted research on several female students in Jakarta and used a qualitative and qualitative descriptive approach. The results of this study are the formation of new perceptions about healthy lifestyles when watching content that in implementing a healthy lifestyle must be included knowledge about nutrition in food ingredients and how to exercise properly.
\end{abstract}

Keywords: audience perception, new media, youtube, influencer, digital content.

\begin{abstract}
Abstrak
Komunikasi merupakan cara dalam menyampaikan pesan atau informasi sehingga mampu mengubah atau menciptakan persepsi. Saat ini internet telah berkembang dengan pesat sehingga Youtube menjadi salah satu media baru yang menjadi saluran untuk mengubah dan menciptakan persepsi. Persepsi yang mampu diciptakan melalui Youtube salah satunya tentang gaya hidup sehat. Tujuan penelitian ini adalah untuk mengetahui persepsi yang timbul setelah menonton konten gaya hidup sehat Yulia Baltschun berdasarkan teori psikologi komunikasi tentang proses terbentuknya persepsi. Penulis melakukan penelitian pada beberapa mahasiswi di Jakarta serta menggunakan pendekatan kualitatif dan bersifat deskriptif kualitatif. Hasil dari penelitian ini adalah terbentuknya persepsi baru mengenai gaya hidup sehat ketika menonton konten bahwa dalam menerapkan gaya hidup sehat harus disertakan pengetahuan tentang nutrisi dalam bahan makanan dan cara melakukan olah raga yang benar.
\end{abstract}

Kata kunci: persepsi khalayak, media baru, youtube, influencer, konten digital.

\section{Pendahuluan}

Komunikasi merupakan suatu hal yang selalu dilakukan oleh manusia, baik komunikasi secara verbal maupun non-verbal. Komunikasi dilakukan dengan tujuan untuk menyampaikan apa yang sedang dirasakan sebagai bentuk informasi kepada orang lain. Komunikasi adalah suatu proses menyampaikan pesan-pesan yang berisikan informasi yang dilakukan oleh seseorang terhadap orang lainnya yang tujuannya adalah untuk memberitahu dan melakukan perubahan baik perubahan sikap maupun perilaku yang dapat dilakukan dengan secara langsung dan tidak langsung, serta melalui media apapun (Effendy: 2015). 
Kecanggihan teknologi saat ini memungkinkan komunikasi dapat dilakukan melalui berbagai platform dan tanpa memerlukan pertemuan secara langsung antara komunikan dan komunikator. Saat ini masyarakat mampu melakukan komunikasi dengan sangat mudah melalui perantara media online seperti Facebook, Twitter, Instagram dan WhatsApp. Namun saat ini komunikasi dapat dilakukan melalui media baru, oleh karena itu media baru menjadi perangkat teknologi elektronik dengan cara penggunaan yang berbeda pula. Sistem teknologi yang dimiliki oleh media elektronik baru ini yaitu melalui sistem kabel atau satelit, miniaturisasi, penyimpanan dan pencarian informasi adapun sistem dalam menyajikan gambar serta pengendalian (McQuail: 2011).

Youtube menjadi salah satu dari bagian media baru yang memiliki berbagai informasi dalam bentuk konten digital yang mampu memberikan edukasi penting bagi masyarakat, baik anak-anak maupun orang dewasa dan tidak hanya digunakan sebagai hiburan, namun dapat juga digunakan sebagai sarana belajar yang menarik dan menyenangkan. Berdasarkan data dari IDN Times tahun 2019 pengguna Youtube mencapai 25 persen dari seluruh populasi di dunia. Berdasarkan survey Google dan kantar TNS pada Januari 2018, masyarakat di Indonesia sebagian besar suka menonton melalui Youtube hampir sama dengan penonton televisi dengan persentase 53 persen penonton Youtube dan 57 persen juga menonton televisi. Hal ini bisa dilihat dari persentase yang telah disebutkan bahwa penonton memiliki minat menonton yang hampir sama besarnya dengan menonton televisi.

Salah satu konten yang dapat ditemukan di Youtube adalah konten tentang gaya hidup sehat. Konten gaya hidup sehat di Youtube diharapkan mampu membuat masyarakat menyadari arti penting hidup sehat dan mempelajari pola hidup sehat serta mampu mengubah persepsi khalayak tentang gaya hidup sehat terutama dalam menerapkan diet serta mengedukasi penontonnya (Isabella, Dida \& Perbawasari: 2019).

Terdapat proses atau tahapan tertentu yang harus dilalui sehingga mampu membentuk persepsi. Suatu obyek yang mampu menyentuh alat indera sehingga mampu menimbulkan stimuli atau rangsangan dan dibantu oleh alat penerima sehingga stimuli tersebut mampu diubah menjadi energi syaraf yang disampaikan ke otak. Di dalam konteks komunikasi, persepsi menjadi suatu proses yang dialami seseorang atau individu untuk memilih, mengorganisasikan serta menafsirkan masukan-masukan informasi yang bertujuan guna membentuk gambaran yang memiliki makna tentang dunia. Persepsi merupakan suatu proses pengamatan mengenai suatu obyek atau peristiwa tertentu dengan menggunakan alat-alat tertentu sebagai medianya.

Setiap manusia memiliki perbedaan tanggapan yang dapat diberikan terhadap suatu obyek. Hal ini disebabkan karena pandangan seseorang dapat dipengaruhi oleh wawasan, pengalaman serta pengetahuan terhadap suatu obyek yang dihadapkan. Terdapat banyak faktor yang dapat mempengaruhi persepsi, baik faktor yang berasal dari dalam diri maupun faktor yang berasal dari luar. Faktor yang terdapat dari dalam diri seseorang dapat berupa pengetahuan yang berasal dari proses pembelajaran sehingga menambah wawasan dan cara berfikir. Sedangkan faktor yang berasal dari luar dapat berupa sistem nilai, norma atau aturan-aturan yang ada di lingkungan atau hasil dari proses perubahan yang terjadi sehingga mampu mempengaruhi persepsi.

Khalayak media dapat memiliki arti atau makna yang berbeda-beda, tergantung dari media perantara yang digunakan serta perspektif yang diambil seperti apa. Sejalan dengan munculnya media baru, perubahan bentuk pada khalayak media 
terjadi. Khalayak media lama akan menjadi tidak terlihat serta terlihat seperti menghilang. Dengan adanya media baru, tidak hanya menimbulkan bentuk-bentuk model komunikasi yang baru tetapi juga menciptakan dan membentuk khalayak media baru. Media baru menawarkan speed and space, di mana media baru mampu menyediakan berbagai peluang baru bagi kehadiran informasi-informasi yang tidak mampu dikemukakan dalam bentuk fisik seperti media konvensional. Format yang ditawarkan oleh media baru lebih inovatif dan menarik (Fenton, 2010: 7).

Dalam definisi lain dikemukakan bahwa media baru merupakan digitalisasi yang mana dari sebuah konsep pemahaman perkembangan zaman mengenai teknologi dan sains. Dari yang semula bersifat manual menjadi otomatis dan dari yang semula bersifat bersifat rumit menjadi lebih ringkas. Media merupakan sesuatu yang akan terus berkembang dari media zaman dahulu hingga sekarang menjadi media modern. Saat ini media baru dapat berbentuk konten digital yang mampu dinikmati oleh banyak orang dengan menampilkan hal-hal menarik. Konten digital dapat digunakan sebagai media untuk mempromosikan ide dan gagasan secara sistematis kepada audiens dan dapat berisi tentang informasi seperti materi berita, pendidikan dan hiburan untuk didistribusikan melalui internet maupun media elektronik lainnya. Konten digital dalam bentuk tulisan dapat dipublikasikan melalui media digital seperti website atau blog sedangkan konten digital dalam bentuk video dapat dipublikasikan melalui Youtube ataupun media sosial lainnya.

\section{Metode Penelitian}

Penelitian ini dilakukan dengan tujuan untuk mengetahui dan memahami perilaku gaya hidup sehat di media terhadap persepsi penontonnya. Dalam penelitian ini penulis menggunakan pendekatan kualitatif dan metode pendekatan studi kasus. Menurut Yin (2013: 18), studi kasus adalah suatu inkuiri empiris yang menyelidiki fenomena di dalam konteks kehidupan nyata, jika batas-batas antara fenomena dan konteks tak tampak dengan tegas dan dimana multisumber bukti dimanfaatkan. Penelitian kualitatif dilakukan dengan maksud untuk memperoleh pemahaman mengenai peristiwa yang sedang atau telah dialami oleh subyek penelitian seperti perilaku, persepsi, motivasi, tindakan, dan lain-lain secara holistik dan dengan cara deskripsi dalam bentuk kata-kata dan bahasa, dalam suatu konteks khusus yang alamiah dengan memanfaatkan berbagai metode-metode alamiah (Moleong, 2017: 6). Subyek utama yang digunakan penulis dalam penelitian ini adalah empat orang mahasiswi berusia 18 hingga 22 tahun yang sudah pernah menerapkan pola hidup sehat dan merupakan pengikut akun Youtube Channel Yulia Baltschun. Obyek penelitian yang digunakan adalah persepsi khalayak yang menonton konten akun Youtube Yulia Baltschun sebagai salah satu influencer gaya hidup sehat.

Metode pengumpulan data yang digunakan oleh penulis adalah dengan melakukan wawancara dengan narasumber, studi kepustakaan guna mencari teoriteori yang berkaitan dengan penelitian melalui buku, referensi skripsi, jurnal atau media lain, kemudian pencarian informasi atau data-data juga dilakukan melalui internet seperti mencari jurnal online sebagai referensi serta melakukan dokumentasi dalam bentuk foto atau catatan-catatan penting yang didapatkan dari hasil wawancara. Dalam melakukan teknik pengolahan data, penulis akan melakukan beberapa metode yang bertujuan untuk menganalisis data yang telah di dapat. Langkah awal yang akan dilakukan adalah dengan cara wawancara mendalam dengan para informan, studi pustaka dan dokumentasi. Dalam menguji keabsahan 
data, penulis menggunakan teknik triangulasi data yaitu menguji kebenaran dan kejujuran subyek atau narasumber dalam mengungkapkan kebenaran yang terjadi menurut apa yang dialami, dirasakan atau dibayangkan (Ruslan: 2017:234).

Dalam penelitian ini, penulis menggunakan tiga metode triangulasi yaitu triangulasi sumber, triangulasi teori dan triangulasi metode. Hal ini dilakukan oleh penulis karena kombinasi dari ketiga model triangulasi tersebut dianggap sudah cukup untuk membuktikan kebenaran dan kejujuran subyek dalam mengungkapkan realitas mengenai apa yang telah dialami, dirasakan dan dibayangkan oleh subyek.

\section{Hasil Temuan dan Diskusi}

Persepsi merupakan salah satu dari hasil proses komunikasi yang dilakukan melalui media perantara seperti media baru. Menurut Nurjaman dan Umam (2012: 36) komunikasi menjadi bentuk interaksi yang dilakukan dengan orang lain dan dapat berupa percakapan biasa yang bersifat membujuk, negosiasi dan mengajarkan. Youtube merupakan salah satu media baru yang menjadi platform membentuk atau menciptakan persepsi baru terhadap suatu hal, salah satunya adalah persepsi mengenai gaya hidup sehat. Perilaku gaya hidup sehat yang dipopulerkan oleh Yulia Baltschun dilakukan dengan mengunggah konten-konten digital dalam bentuk video melalui platform Youtube. Hal ini dilakukan dengan tujuan untuk menciptakan persepsi baru tentang gaya hidup sehat di masyarakat.

Perilaku gaya hidup sehat yang dipopulerkan oleh Yulia Baltschun melalui konten di Youtube mampu mengubah persepsi penontonnya tentang gaya hidup sehat. Persepsi awal tentang gaya hidup sehat hanya sekadar menjaga pola makan, melakukan olahraga teratur. Penonton tidak memiliki pengetahuan tentang aturanaturan dan tata cara menerapkan pola hidup sehat yang tidak boleh dilakukan secara sembarangan. Bahkan beberapa orang malas menerapkannya karena dianggap sulit dan menyiksa. Namun setelah menonton konten gaya hidup sehat yang dilakukan oleh Yulia Baltschun, beberapa orang mulai menciptakan persepsi baru mengenai gaya hidup sehat.

Persepsi awal yang muncul ketika mendengar tentang gaya hidup sehat adalah menjaga asupan makanan dengan mengkonsumsi buah dan sayur serta olah raga. Anggapan bahwa menerapkan gaya hidup sehat atau diet itu menyakitkan juga sering didengar. Namun setelah menonton konten-konten Yulia Baltschun terbentuk persepsi bahwa dalam gaya hidup sehat tidak hanya menjaga asupan makanan, tetapi juga mengatur pola makan dengan mencari tahu bahan makanan apa saja yang mengandung nutrisi yang baik bagi tubuh, menghitung jumlah kalori, mencari tahu teknik memasak yang benar agar nutrisi dalam, olahraga teratur dan cara melakukannya agar tidak mengalami cedera serta istirahat yang cukup.

Beberapa informan menganggap bahwa persepsi awal mereka salah karena gaya hidup sehat itu ternyata harus dilakukan dengan tepat dan disesuaikan dengan kondisi tubuh masing-masing. Pada awalnya mereka ada yang masih menganggap enteng tentang pola hidup sehat dan kesehatan sendiri serta berpikir bahwa hanya perlu mengkonsumsi makanan yang sehat tanpa harus istirahat yang cukup. Namun satu dari empat informan yaitu informan 3, menganggap bahwa persepsi awal yang ia miliki tidak salah. Ia menjelaskan bahwa persepsi yang ia miliki di awal tidak salah, hanya saja cara dalam menerapkan gaya hidup sehat yang salah. Konten-konten yang dibuat oleh Yulia Baltschun selalu memberikan edukasi penting terkait penerapan gaya hidup sehat. Sebelum membuat konten, Yulia selalu mencaritahu melalui buku, 
jurnal ilmiah dan sumber terpercaya lainnya. Oleh karena itu, penonton dari setiap konten yang beliau unggah dapat memiliki informasi yang edukatif dan berdasarkan fakta, sehingga informasi yang beliau bagikan menjadi bermanfaat.

Hal ini sesuai dengan teori persepsi yang dikemukakan oleh Rakhmat (2018: 520), bahwa persepsi yang timbul dipengaruhi oleh stimuli. Konten gaya hidup sehat yang dipopulerkan Yulia Baltschun menjadi stimuli terhadap penontonnya. Hal ini diproses dan dipahami oleh penontonnya bahwa gaya hidup sehat tidak hanya mengkonsumsi buah dan sayur saja. Persepsi yang timbul setelah menonton konten gaya hidup sehat yang dipopulerkan oleh Yulia Baltschun adalah bahwa dalam menerapkan gaya hidup sehat tidak boleh dilakukan dengan sembarangan. Hal ini berlaku dalam semua aspek penerapan gaya hidup sehat tersebut.

Rakhmat dalam buku Psikologi Komunikasi mengemukakan empat proses terbentuknya persepsi yakni stimulus menjadi proses persepsi pertama yang didapatkan oleh khalayak berupa tayangan konten Yulia Baltschun yang dilakukan melalui perantara media Youtube. Kemudian dalam proses registrasi persepsi, informasi mengenai tata cara menerapkan pola hidup sehat tersebut dilihat dan didengar oleh khalayaknya sehingga informasi tersebut akan diserap.

Proses interpretasi persepsi terjadi ketika khalayak melihat bagaimana gaya hidup sehat yang dilakukan oleh Yulia. Ketika menonton tayangan konten gaya hidup sehat, mereka menyerap informasi serta mendalami penjelasan tentang mengatur pola makan, menghitung kalori hingga melakukan olahraga yang tepat. Tayangan konten tersebut menggantikan persepsi awal mereka yang sebelumnya menganggap bahwa gaya hidup sehat hanya dilakukan dengan mengatur pola makan tanpa mengetahui kandungan gizi pada makanan dan olahraga saja. Namun setelah menonton mereka mempersepsikan bahwa gaya hidup sehat merupakan hal yang penting untuk dilakukan dengan cara mengatur pola makan yang benar sesuai dengan 4 sehat 5 sempurna, mengatur berapa jumlah kalori yang harus dikonsumsi, melakukan olah raga dengan gerakan yang tepat dan teratur. Setelah itu timbul umpan balik sebagai proses persepsi yang di mana para informan merasa termotivasi ketika menonton atau merasa terinspirasi oleh konten Yulia Baltschun, sehingga mereka mulai menerapkan gaya hidup sehat dalam keseharian mereka. Hal ini menunjukkan bahwa persepsi yang timbul setelah menonton konten tersebut mampu memberikan reaksi positif terhadap informan.

Berdasarkan hasil wawancara peneliti dengan para informan, peneliti menyimpulkan bahwa komunikasi merupakan aktivitas dalam menyampaikan informasi melalui media perantara yang mampu menciptakan persepsi khalayak terhadap suatu hal dan dalam bentuk konten berupa gambar, audio dan video. Hal ini diperkuat dengan kemudahan khalayak dalam mengakses media guna memperoleh atau menyebarkan informasi. Seperti yang dilakukan oleh Yulia Baltschun sebagai influencer dengan memiliki jumlah pengikut yang banyak, maka proses komunikasi yang dilakukan guna menyampaikan pesan-pesan berupa penerapan gaya hidup sehat yang benar melalui Youtube dalam bentuk konten digital, mampu menimbulkan persepsi khalayak penontonnya mengenai penerapan gaya hidup sehat dalam kehidupan sehari-hari. Khalayak yang menganggap bahwa gaya hidup sehat sulit diterapkan dalam kehidupan sehari-hari menjadi memiliki informasi dan edukasi yang didapatkan dari konten video yang dibuat oleh Yulia Baltschun sebagai seseorang yang ahli dan memiliki kemampuan untuk menciptakan persepsi melalui media. 


\section{Simpulan}

Persepsi yang dimiliki oleh penonton tentang gaya hidup sehat masih sebatas menjaga asupan makanan dan melakukan olahraga tanpa mengetahui fungsi dari olahraga yang dilakukan. Para informan dalam penelitian ini mempersepsikan bahwa dalam menerapkan gaya hidup sehat harus disertai dengan edukasi dan tidak boleh dilakukan secara sembarangan. Edukasi mengenai gaya hidup sehat tidak hanya tentang makanan, namun hal-hal apa saja yang harus dipersiapkan seperti mengenal gizi yang diperlukan tubuh, menghitung jumlah kalori yang harus dikonsumsi dan dibakar, jenis-jenis olahraga yang bisa menurunkan berat badan atau membentuk bagian tubuh tertentu serta hal-hal apa saja yang boleh dan tidak boleh dilakukan ketika menerapkan gaya hidup sehat tersebut.

Penulis menyarankan agar nantinya dalam perkembangan Ilmu Komunikasi lebih banyak lagi membahas teori tentang persepsi, media baru terutama yang membahas tentang Youtube. Bagi masyarakat yang berkeinginan untuk menerapkan gaya hidup sehat sebaiknya melakukan pencarian informasi bagaimana cara menerapkannya melalui sumber-sumber terpercaya seperti jurnal, buku, ahli gizi atau dokter agar penerapan gaya hidup disesuaikan dengan kondisi tubuh masing-masing.

\section{Ucapan Terima Kasih}

Penulis mengucapkan terima kasih kepada banyak pihak yang telah membantu penulis, terutama kepada dosen Fikom Untar serta kepada informan yang sudah membantu penulis dalam menjawab dan memberikan informasi mengenai perubahan persepsi yang dialami, serta kepada keluarga dan teman-teman penulis yang turut memberikan dukungan pada penulis dalam menyelesaikan penelitian ini.

\section{Daftar Pustaka}

DeVito, Joseph A. (2013). Komunikasi Antar Manusia. Tangerang: Karisma Publishing Group.

Isabella, S., Dida, S., \& Perbawasari, S. Personal Branding Yulia Baltschun Sebagai Diet Influencer Melalui Youtube. Jurnal Ilmu Komunikasi. (2019). Vol. 5, No. 2 Hal 357-371.

Moleong, Lexy J. (2017). Metode Penelitian Kualitatif. Bandung: PT Remaja Rosdakarya.

Rakhmat, Jalaludin. (2018). Psikologi Komunikasi. Bandung: PT Remaja Rosdakarya.

Sukendro, G., \& Cecariyani, A. Analisis Strategi Kreatif dan Tujuan Konten Youtube (Studi Kasus Konten Prank Yudist Ardhana). Jurnal Ilmu Komunikasi. (2018). Vol. 2, No. 2, Hal 495-502.

Unchjana Effendy, O. (2015). Dinamika Komunikasi. Bandung: PT Remaja Rosdakarya. 